\title{
Growth dynamics of Geoffroea decorticans and Parkinsonia praecox and their response to climate in arid and semiarid environments in Argentina
}

\author{
Dinámica de crecimiento y relación con el clima de Geoffroea decorticans y Parkinsonia praecox \\ en ambientes áridos y semiáridos de Argentina
}

\author{
Maria Alicia Cendoya ${ }^{\text {a*, }}$, Marcia Micca ${ }^{\text {b }}$, Stella Marys Bogino ${ }^{\text {b }}$ \\ *Autor de correspondencia: ${ }^{a}$ Instituto Nacional de Tecnología Agropecuaria, EEA San Luis, Villa Mercedes, San Luis, Argentina, \\ tel.: +54 2657204863, malicia.cendoya@gmail.com \\ ${ }^{\mathrm{b}}$ Universidad Nacional de San Luis, Departamento de Ciencias Agropecuarias, Villa Mercedes, San Luis, Argentina.
}

\begin{abstract}
SUMMARY
Arid and semiarid environments dominate the Earth's surface and are very vulnerable to global change. Chañar (Geoffroea decorticans) and brea (Parkinsonia praecox) are two ubiquitous woody species of these environments. They grow in degraded forests, strongly modified areas and as a main component of secondary forests. Despite the value of both species, little is known about their growth dynamics and their relationship with climate. The objective of this research was to determine their dendrochronological potential and the connection between growth and climate variables. Anatomical and standard dendrochronological methods were applied. First of all, we stated the anatomical characteristics that allowed us to detect tree-ring boundaries (terminal parenchyma and variation in the shape of vessels). Further, after dating and measurement of tree rings we determined significant correlation between series, which means a common growth signal among trees as a result of environmental variable effects. Trees were not older than 40 years. Mean annual radial growth was $3.37 \mathrm{~mm}(\mathrm{SD} \pm 0.71)$ and $2.16 \mathrm{~mm}(\mathrm{SD} \pm 0.61)$ for chañar and brea, respectively. Finally, chañar and brea had a negative growth-mean temperature association. Rainfall affected chañar and brea growth in summer previous to the growing season. Southern Oscillation Index (SOI) had an inverse association with growth of brea. This means, in the case of brea, a significant association with local (temperature and rainfall) and global (SOI) climate variables. These results evidenced the growth dynamics of both species and their value for dendroclimatological studies for the first time.
\end{abstract}

Key words: dendrochronology, dendroclimatology, wood anatomy, espinal, monte.

\section{RESUMEN}

Los ambientes áridos y semiáridos dominan la superficie terrestre y son muy vulnerables en el contexto actual del cambio global. El chañar (Geoffroea decorticans) y la brea (Parkinsonia praecox) son especies que crecen en estos ambientes en bosques degradados, en áreas severamente transformadas o bien como componentes secundarios de los bosques maduros. A pesar de la importancia de ambas especies poco se conoce sobre su dinámica de crecimiento y su relación con el clima. El objetivo de este trabajo fue: determinar el potencial dendrocronológico y el vínculo entre el crecimiento y las variables climáticas de ambas especies. Se aplicaron métodos anatómicos y dendrocronológicos estándares. En primer lugar, establecimos las características anatómicas que nos permitieron detectar los límites de los anillos de crecimiento de los árboles. En segundo lugar, determinamos una correlación significativa entre las series, lo que significa una señal de crecimiento común entre los árboles como resultado de los efectos de las variables ambientales. Las series medidas en ambas especies permitieron estimar correlaciones significativas que demuestran una señal común de crecimiento ambiental. El crecimiento radial medio para ambas especies fue de 3,37 (DS $\pm 0,71)$ y 2,16 (DS $\pm 0,61)$ respectivamente. La longevidad no superó los 40 años. Por último, el crecimiento de chañar y brea tuvieron una asociación inversa con la temperatura media. La precipitación afectó los crecimientos de chañar en el verano y de la brea en la estación previa al crecimiento. El IOS (Índice de Oscillation Sur) tuvo una asociación inversa con el crecimiento de la brea. Esto implica, en el caso de la brea, una asociación significativa con variables climáticas locales (temperatura y lluvia) y globales (IOS). Estos resultados señalaron por primera vez la dinámica de crecimiento de ambas especies y su valor para estudios dendroclimatológicos.

Palabras clave: dendrocronología, dendroclimatología, anatomía del leño, monte, espinal. 


\section{INTRODUCTION}

Arid and semiarid environments occupy more than sixty percent of Argentina's landscape. The driest area of Argentina's pampas region is covered by forests dominated by Prosopis species (Oyarzabal et al. 2018). Chañar (Geoffroea decorticans (Gill. ex Hook. et Arn.) Burkart) (Fabaceae, Papilionoideae) and brea (Parkinsonia praecox (Ruiz et Pav.) Hawkins) (Fabaceae, Caesalpinioideae) are two woody species that grow in these environments. They are pioneers with individuals recruiting massively after disturbances in severely transformed areas or degraded forests (Anderson et al. 1970).

Geoffroea decorticans is an antagonistic species from the anthropic point of view. On the one hand, it is considered an invasive woody shrub of the adjacent psammophilous grasslands that belong to the pampean grassland steppe dominated by $\mathrm{C} 4$ photosynthesis species of the genus Aristida, Bothriochloa, Chloris, Elionurus, Eragrostis, Poa, Schizachyrium, Sorghastrum, Sporobolus and Stipa (Anderson 1976). On the other hand, in the forests of Chaco, Monte and Espinal, it is a main component of the secondary forests (Giménez and Moglia 2003). Parkinsonia praecox grows in places known as peladales, which are highly degraded areas previously affected by fire and overgrazing, where it forms homogeneous forests or breales (Martínez Carretero 1986, Paez and Marco 2000).

Both species are the first to be established after severe disturbance, especially fire (Medina et al. 2000, Dussart et al. 2011). Considering that disturbance, including fires, is an essential component of forest systems (Oliver and Larson 1996) and that both species react in a similar way after its occurrence, it is essential to know how its temporal growth dynamic is. However, there is no information about it. Furthermore, in this context of global change, the value of forests as providers of ecosystem services has been reconsidered and the quantification of biomass for estimating the capacity to fix carbon is one of the most interesting variables in the world (Bar-on et al. 2018). Therefore, being able to estimate the growth rate of woody species makes it possible to accurately quantify this variable.

Two useful tools are available to evaluate the dynamics of forest systems over time: repeated measurements in permanent plots or an analysis applying dendrochronological techniques. Dendrochronology is the science that studies environmental events recorded in the growth rings of woody species. In this way, it is possible to annually analyze the relationship between individuals and the environment (Speer 2010). One of the most relevant applications of a growth-ring analysis is its use to establish the relationship between annual growth and climatic variables and, consequently, the reconstruction of past climatic conditions. Previous dendrochronological studies in the arid and semi-arid environments of Argentina had analyzed the most long-lived species with the highest timber value with special emphasis on the genus Prosopis (Morales et al. 2005, Villagra et al.
2005, Dussart et al. 2011, Bogino et al. 2015). Therefore, knowing about the growth dynamics of pioneer species will complement these studies and establish the interconnection between main species and those that are codominant or intermediate in a secondary forest (Gorzelak et al. 2015).

Despite the fact that $G$. decorticans is a widely distributed species in arid and semi-arid areas of Argentina, Bolivia, Chile, Uruguay and Peru (figure 1AB), there are no previous dendrochronological studies. To date, the approach has been limited to describe its anatomy and growth-ring width (Giménez et al. 2013). P. praecox has a wider geographic distribution area than that of $G$. decorticans: from the Sonoran Desert in Mexico $32^{\circ} \mathrm{N}$ to the south of the Argentine Chaco $35^{\circ} \mathrm{S}$ and from sea level to $2000 \mathrm{~m}$ asl (Schuch and Kelly 2008) (figure 1AC).

Before establishing the dendrochronological potential of any species, it is necessary to determine whether its growth rings are identifiable. Previous studies on the anatomy of G. decorticans are contradictory: on the one hand, according to Tortorelli (1956), differentiating tree rings is uncertain due to its diffuse semi-circular porosity, although on the other hand, further studies indicate that chañar is one of the few species from the Argentine Chaco that presents well-defined tree rings (Giménez 2009). A 33-yearold $G$. decorticans forms rings with an average thickness of $4.7 \mathrm{~mm}$ which implies that chañar is a species with the highest annual growth in the Semi-arid Chaco (Gimenez 2009). Regarding P. praecox, growth rings can be differentiated due to their semi-circular porosity (Tortorelli 1956). Previous studies in the Guajira of Colombia pointed out its association with regional and local climate variables (Ramirez and del Valle 2011) consequently, there is a need of complementing these previous studies to establish a common pattern of the species response to climate variables.

Considering that there are no studies on both species that determine their growth dynamics and relationship with environmental variables at their southern distribution area, our research questions are: Is it possible to successfully date the growth rings and analyze the temporal growth dynamics in relation to climate for both species? May climate-growth association determine the dynamics of both species? Therefore, the working hypothesis is: both species are possible to be dated as previous studies encourage us to think of the possibility of detecting tree ring boundaries and that their ubiquity responds to a scarce relationship with climatic variables. The objectives of this research are: a) to determine the anatomical characteristics of both species for their possible dating and $b$ ) from the feasibility of this fact, to reconstruct the growth dynamics and the relationship with climate.

\section{METHODS}

Sampling sites. The study site for Geoffroea decorticans was in the so-called sandy pampas (natural area \#9 of the province of Cordoba; $33^{\circ} 32^{\prime} 11.4^{\prime}$ 'S, $65^{\circ} 00^{\prime} 01.3^{\prime \prime} \mathrm{W}$ ) (figure $2 \mathrm{~A}$ ). The topography of the area is undulating or gently 


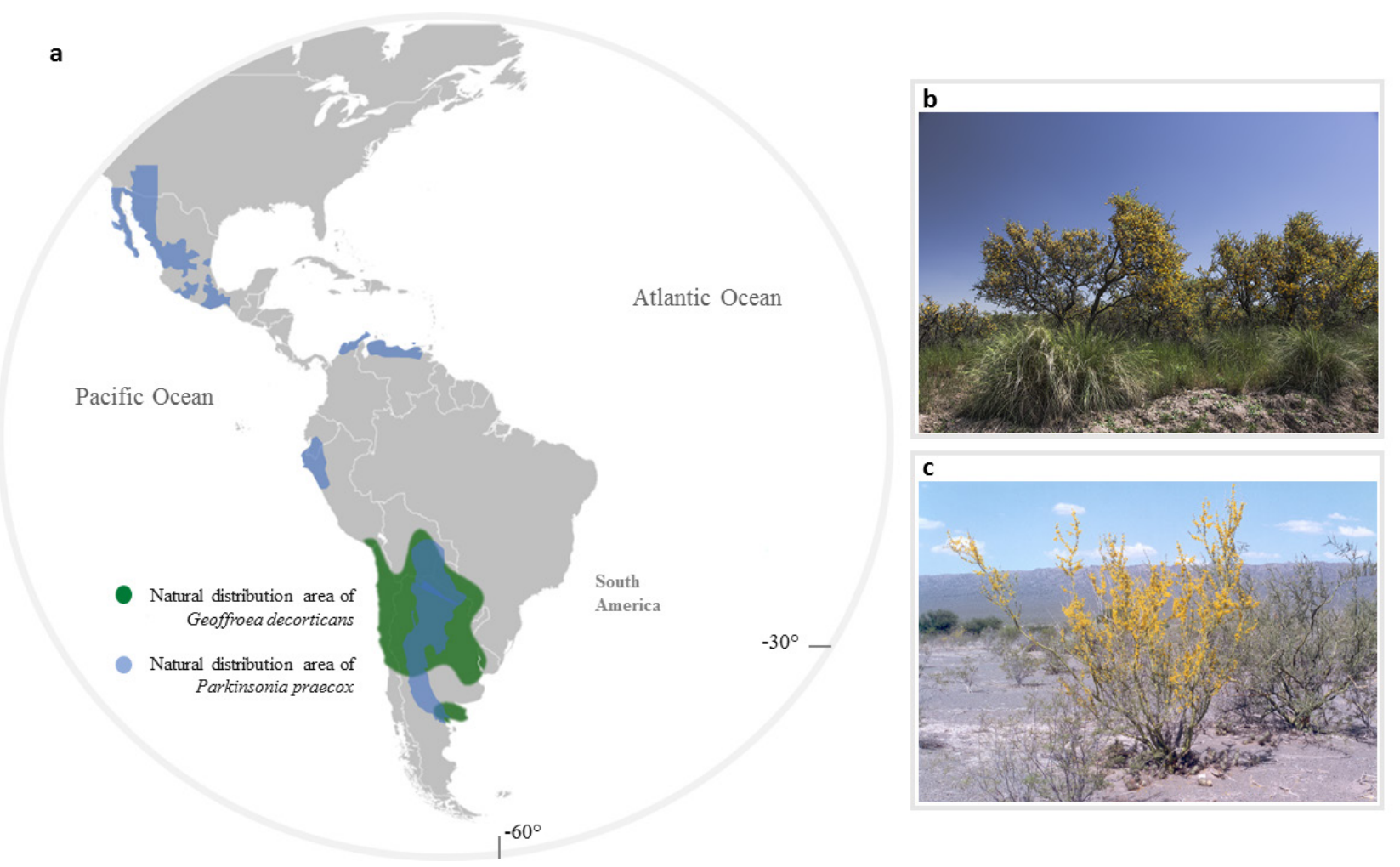

Figure 1. Distribution area of chañar (Geoffroea decorticans) and brea (Parkinsonia praecox) (A). Photographs of chañar (B) and brea (C). Área de distribución de chañar (Geoffroea decorticans) y de brea (Parkinsonia praecox) (a). Fotografías de chañar (b) y brea (c).

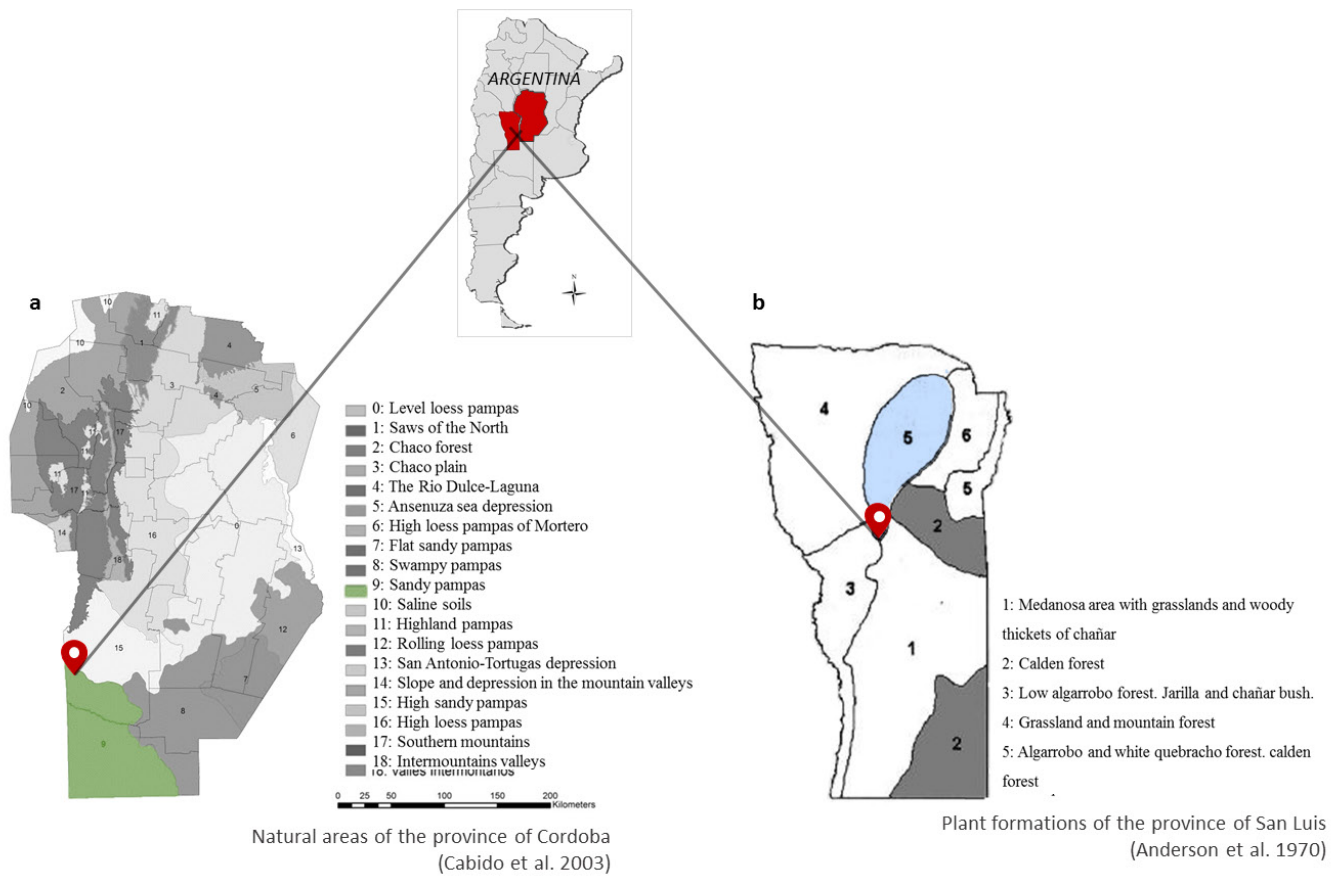

Figure 2. Sampling sites for chañar (Geoffroea decorticans) (A) and brea (Parkinsonia praecox) (B) according to the phytogeographic distribution in the center of Argentina.

Sitios de muestreo de chañar (Geoffroea decorticans) (a) y de brea (Parkinsonia praecox) (b) de acuerdo con la distribución fitogeográfica correspondiente para el centro de Argentina. 
undulating due to the presence of dunes of different ages. The predominant soils are Entisols (with the dominance of the typical Ustipsaments). Soils are sandy, shallow, with little differentiation of horizons, excessively drained, without aggregation and with low content of organic matter (Cabido et al. 2003). Climate is temperate (Köppen 1931) with a wide range of thermal oscillation (absolute maximums of $44{ }^{\circ} \mathrm{C}$ and minimums of $-11^{\circ} \mathrm{C}$ ). Annual rainfall reaches $600 \mathrm{~mm}$ and is mainly distributed between October and March (Cabido et al. 2003). Altitude is of approximately $500 \mathrm{~m}$ a.s.l. This region is part of Espinal Phytogeographic Province (Cabrera 1976). Probably, in the past, vegetation was calden (Prosopis caldenia Burkart) forests and grasslands. However, the interpretation of the predominant landscape until the settlement of the Spanish conquerors in the 16th century is difficult due to practically non-existent written testimonies. Nowadays, the area is affected by wind erosion due to land use changes and agricultural activities. In this context of disturbance, $G$. decorticans colonizes the ridges of dunes formed by wind erosion.

The Parkinsonia praecox sampling site was located in the southern extreme part of arid Chaco within the area of grasslands and mountain forests (plant formation \#5 of the province of San Luis (33⒉ $8^{\prime} 43.81^{\prime \prime}$ 'S, 66 $26^{\circ}$ '16.63”W) (Anderson et al. 1970) (figure 2B). The area presents a physiography of arid foothills. Entisols are the predominant soils with low content of organic matter and high susceptibility to wind and water erosion (Peña Zubiate et al. 1998). Annual rainfall is between 400 and $500 \mathrm{~mm}$ and it is characterized by strong seasonal, annual and multi-year variability (Karlin et al. 2013). Average annual temperature is $17.8{ }^{\circ} \mathrm{C}$ and the average temperature of the warmest (January) and coldest (July) months is 25 and $9{ }^{\circ} \mathrm{C}$, respectively. Altitude varies between 450 and $500 \mathrm{~m}$ asl. Vegetation is characterized as a disetaneous secondary forest mostly dominated by Aspidosperma quebracho blanco Griseb. and Prosopis species (15-18 m high) accompanied by a shrubby layer (Anderson et al. 1970).

For anatomical studies, stem cross sections were cut with a chainsaw at $20 \mathrm{~cm}$ high from three individuals of each species. Light microscopic sections of $15 \mu \mathrm{m}$ thickness were obtained from transversal sections using a sliding microtome Leica, Hn 40 Model. Afterwards, the samples were whitened with sodium hypochlorite and dehydrated with xylol. Finally, they were colored using Safranin (1\%), fast green and $80^{\circ}$ alcohol and sealed using Entellán (D'Ambrogio de Argüeso 1986). For wood description, the terminology of the List for the identification of hardwoods was used (IAWA Committee 1989).

For dendrochronological studies, cross sections at the tree base were taken using a chainsaw. In July 2016, 14 dominant individuals of $G$. decorticans (10 alive and 4 dead) and in January 2011, 15 living dominant trees of P. praecox were sampled. The basal cross-sections were polished using sandpaper with increasingly fine grain size to try to visualize tree rings (40-600 sieves in $\left.^{-2}\right)$. The rings were visualized and demarcated with the help of an Olympus SZ61 magnifying glass ( 0.9 to $4 \mathrm{X}$ ). Two different radii per cross section were determined. For the correct assignment of the calendar year to each ring, the convention of Schulman (1956) for the southern hemisphere was applied. The rings were measured with a Unislide TA 4020H1-S6 Velmex equipment ( $0.01 \mathrm{~mm}$ precision). The validity of the dating was verified with the COFECHA program that compared the variability of the width of the rings to correctly establish the calendar year of each ring and to determine false or missing rings (Grissino-Mayer 2001, Fritts 2001). Mean correlation between series and mean sensitivity (growth variability between two consecutive years) were determined. The age of trees must be determined with an annual or absolute level of precision, which is essential for any dendrochronological study, since the correct and precise estimation of the calendar year in which each growth ring was formed is a fundamental condition for dating (Speer 2010). Furthermore, the date of establishment of each individual can be stated.

After obtaining the chronologies of the ring-width index of both species, the series were standardized to maximize high frequency variability possibly associated with climate. The standardization applied was first of all a negative exponential and, after, a 40-year spline that generated three chronologies of average indices for each species (row, standardized and residual). The residual chronology of each species was compared with the climatic variables. To establish the validity of chronologies, three indicators were used: signal-to-noise ratio (SNR), Expressed Signal of the Population (EPS) and variance of the first vector. The climatic data used were: monthly precipitation and monthly mean temperature of INTA Villa Mercedes $\left(33^{\circ} 39^{\prime} 07.3^{\prime \prime} \mathrm{S}, 65^{\circ} 25^{\prime} 11.2^{\prime \prime} \mathrm{W}\right)$ and San Luis $\left(33^{\circ} 15^{\prime} 36.0^{\prime \prime} \mathrm{S}, 66^{\circ} 14^{\prime} 24.0^{\prime \prime} \mathrm{W}\right)$ meteorological stations. Monthly SOI (Southern oscillation index) were obtained from the Climatic Research Unit of the University of East Anglia. SOI is a standardized index of water sea level pressure oscillation between Tahiti and Darwin (Australia) that determines El Niño and La Niña events (Ropelewski and Jones 1987). The DENDROCLIM 2002 program (Biondi and Waikul 2004) was applied to analyze the relationship between climatic variables and ring width indices. Statistical analyses in both species were performed with the Infostat version 12 package (Di Rienzo et al. 2012).

\section{RESULTS}

Anatomical analysis. Geoffroea decorticans has a semicircular porosity. The vessels are circular or oval, solitary, multiple short vessels (2-3) and occasionally have multiple long radials (4-5 vessels). In latewood, the few vessels are grouped in clusters, sometimes in ulmoid to semi-ulmoid positions and parallel to the rays. Many pores are occluded by tylosis and xylochromatic substances. The parenchyma is confluent. Normally, at the limit of each growth ring there is a band of 2-5 cells of terminal parenchyma that 
allows the delimitation of the border (figure 3A). The radii are linear. Parkinsonia praecox has semicircular porosity, solitary or multiple short vessels (2-6) where some of them are grouped. Vessels are circular or oval with linear rays and irregularly distributed. The axial parenchyma is confluent or paratracheal (figure 3B).

Dendrochronological analysis. The dating of Geoffroea decorticans and Parkinsonia praecox was possible (figure 4A and 4B) and consequently the first chronologies for both species were constructed since the sampled indivi- duals could be correctly dated. The establishment date was estimated for the four dead specimens of G. decorticans, which died by both natural and anthropic causes. On the other hand, it was possible to co-date the time series of both species to obtain a master chronology. The statistics that characterize both chronologies are adequate to continue with a dendroclimatic study (table 1).

The mean radial growth of the 14 individuals of $G$. decorticans was $3.37 \mathrm{~mm}(\mathrm{SD} \pm 0.71 \mathrm{~mm})$ and the extreme values ranged between $1.99 \mathrm{~mm}$ and $5.57 \mathrm{~mm}_{\text {year }}{ }^{-1}$ for trees between 16 and 29 years old (figure 5A and 5B). The

a

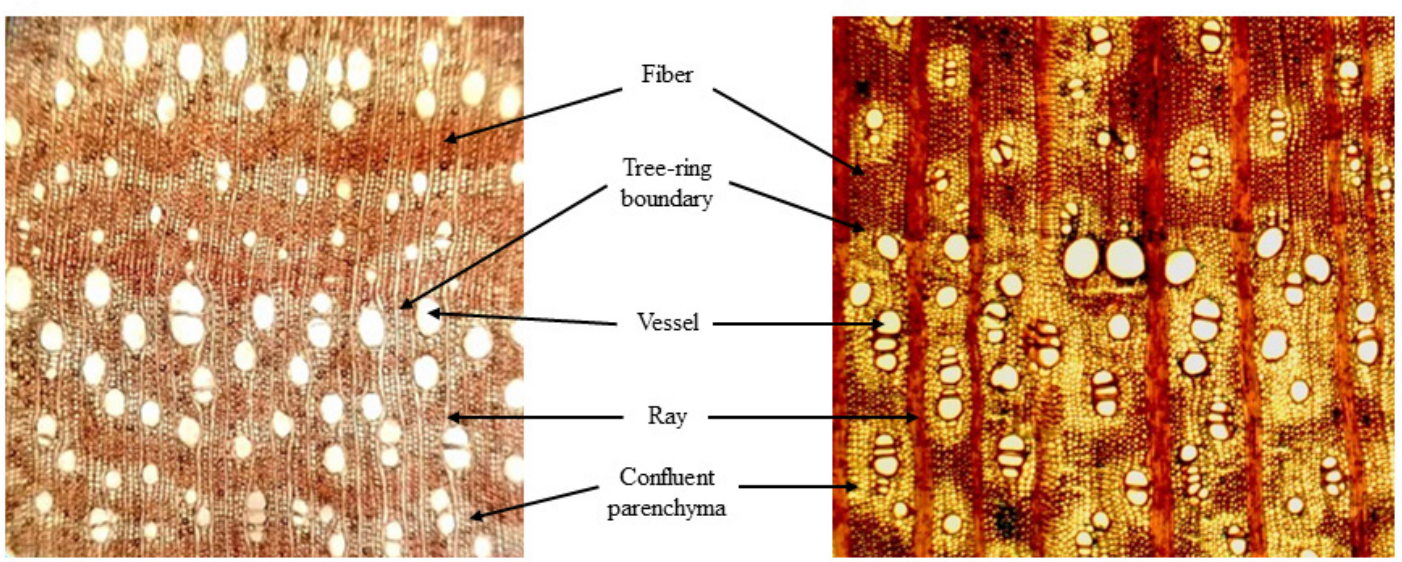

Figure 3. Wood anatomy of chañar (Geoffroea decorticans) (A) and brea (Parkinsonia praecox) (B) in transversal sections. Magnifying glass (4X).

Anatomía de la madera de chañar (Geoffroea decorticans) (a) y de brea (Parkinsonia praecox) (b) donde se visualizan elementos que conforman el leño y los distintos anillos de crecimiento (Zoom 4X).

a

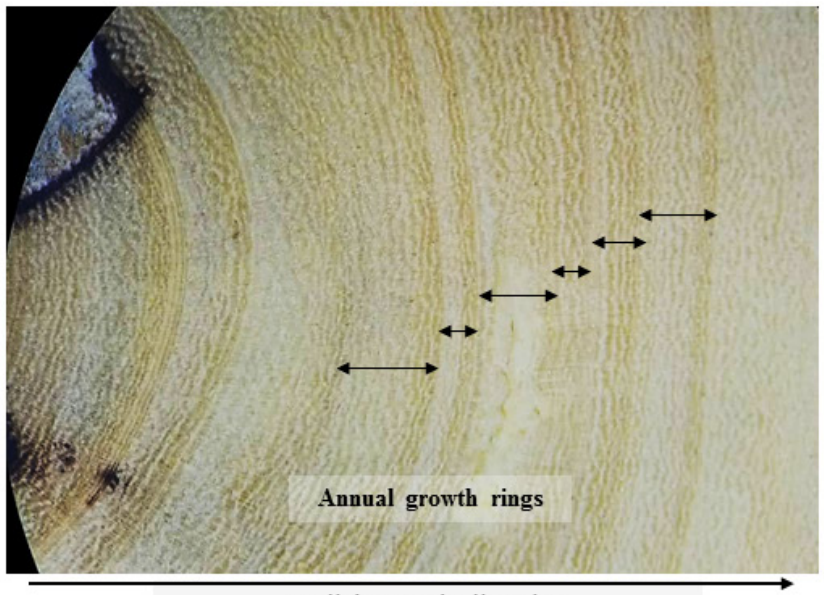

Radial growth direction b

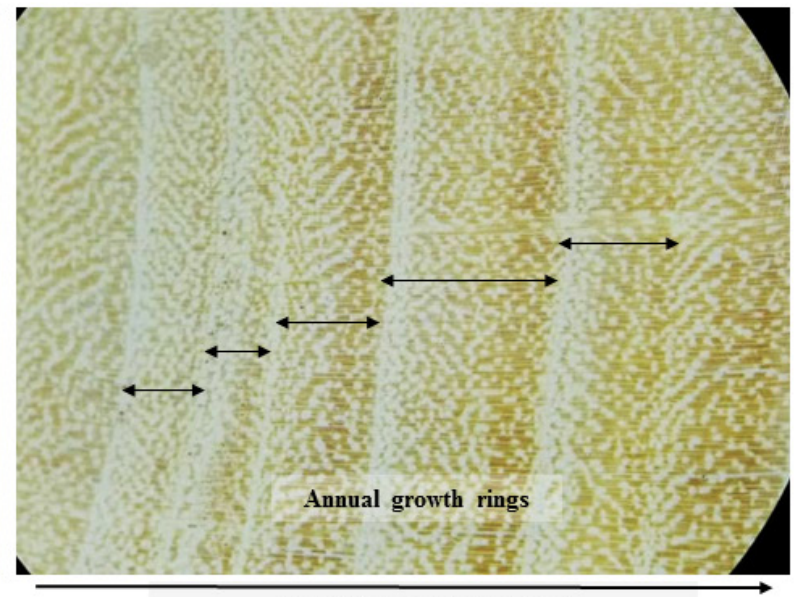

Radial growth direction

Figure 4. Demarcation of chañar (Geoffroea decorticans) (A) and brea's (Parkinsonia praecox) (B) growth rings for dating using Olympus SZ61 magnifying glass (0.9 to $4 \mathrm{X})$.

Demarcación de los anillos de crecimiento de chañar (Geoffroea decorticans) (a) y de brea (Parkinsonia praecox) (b) para datación mediante lupa Olympus SZ61 (0,9 a 4X). 
Table 1. Statistical values that characterize the chronologies of chañar (Geoffroea decorticans) and brea (Parkinsonia praecox). Valores estadísticos para las cronologías de ancho de anillo de chañar (Geoffroea decorticans) y de brea (Parkinsonia praecox).

\begin{tabular}{lcc}
\hline & Geoffroea decorticans & Parkinsonia praecox \\
\hline Number of trees & 14 & 15 \\
Number of series & 27 & 30 \\
Master series & $1987-2015$ & $1971-2009$ \\
Mean annual radial growth (mm) & $3.37(\mathrm{SD} \pm 0.71)$ & $2.16(\mathrm{SD} \pm 0.61)$ \\
Mean sensitivity & 0.32 & 0.4 \\
Correlation between series & 0.52 & 0.38 \\
SNR (residual) & 2.03 & 7.87 \\
EPS & 0.67 & 0.88 \\
Variance of the first vector (\%) & 31.34 & 42.28 \\
\hline
\end{tabular}

Mean sensitivity: tree-ring width variability between two subsequent years, SNR: signal to noise radio, EPS: Expressed population signal.
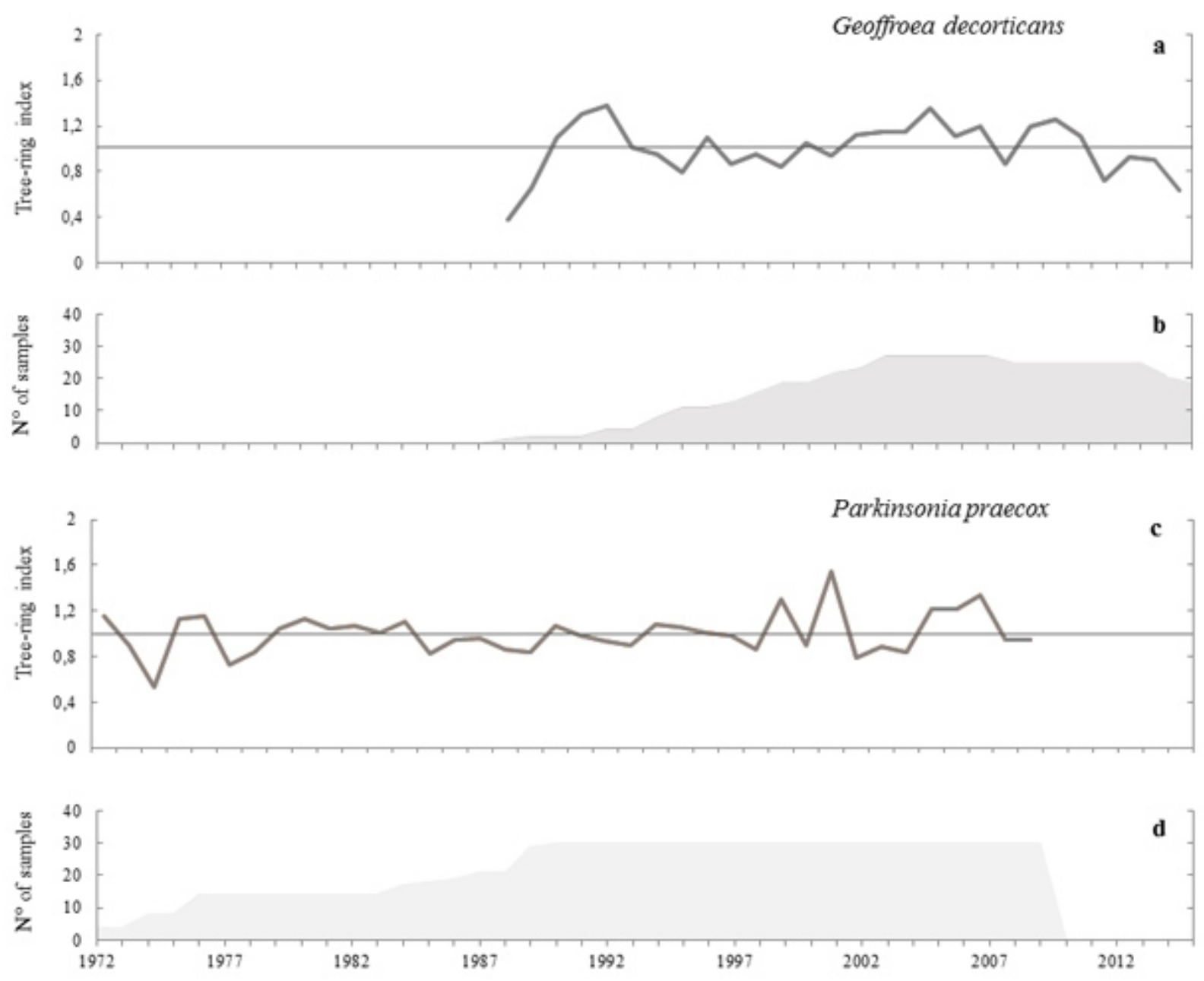

Figure 5. Standardized chronologies of chañar (Geoffroea decorticans) and brea (Parkinsonia praecox) for arid and semi-arid environments of Argentina. Indexed growth rate for each species over time (A and C) and number of samples used in each chronology (B and D).

Cronologías estandarizadas de chañar (Geoffroea decorticans) y de (Parkinsonia praecox) para ambientes áridos y semiáridos de Argentina. Índice de crecimiento para cada especie a lo largo del tiempo (a y c) y número de muestras utilizadas en cada cronología (b y d). 
mean radial growth of the 15 individuals of $P$. praecox was $2.16 \mathrm{~mm}(\mathrm{SD} \pm 0.61 \mathrm{~mm})$ and the extreme values ranged between 1.15 and $3.07 \mathrm{~mm}$ year ${ }^{-1}$ for trees between 23 and 39 years old (figure 5C and 5D).

Dendroclimatic analysis. The analysis of the relationship between the residual chronology of tree-ring widths and the climatic variables determined that: $G$. decorticans had an inverse and significant relationship with the temperatures of May (autumn) and July (winter) prior to the growing season, and with May at the end of the growing season (figure 6). P. praecox showed an inversely significant relationship with temperature throughout the growing season. In relation to rainfall, $G$. decorticans showed an inverse association in summer (December) and P. praecox an inverse association previous to the growing season (May and July) and a positive association in summer (January). Unlike $G$. decorticans, $P$. praecox had an inverse relationship with global weather patterns such as SOI during May prior to the growing season and at the end of it (from May to September) (figure 6).

\section{Geoffroea decorticans}

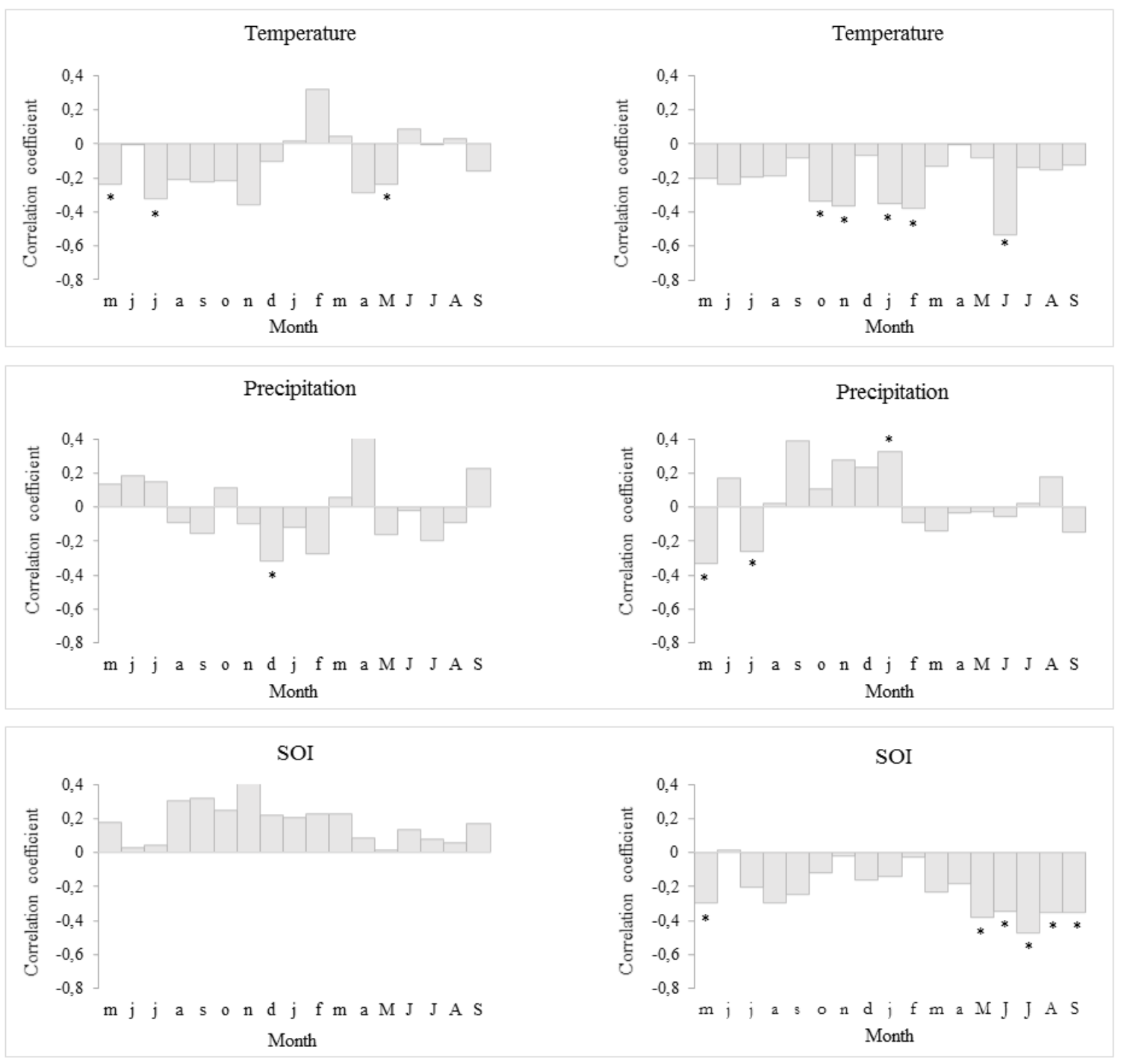

Figure 6. Pearson's correlation coefficients (bars) that indicate the effect of local and global climatic variables chañar (Geoffroea decorticans) and brea's (Parkinsonia praecox) growth at both sites during the 1972-2015 period. The analyzed period covered from May before growth to September of the current growing year $(* P<0.05)$.

Coeficientes de correlación de Pearson (barras) entre las cronologías residuales de chañar (Geoffroea decorticans) y de brea (Parkinsonia praecox) y las variables climáticas locales (temperatura media mensual y precipitación mensual) y globales (Índice de Oscilación del Sur) para ambos sitios durante el período 1972-2015. El período analizado va desde el mes de mayo del año previo al crecimiento y se extiende hasta septiembre donde finaliza el período anual de crecimiento $(*=P<0,05 R)$. 


\section{DISCUSSION}

Anatomical observations, mainly the presence of terminal parenchyma, made it possible to establish the feasibility of dating both species. The results obtained through the analysis of the growth rings of Geoffroea decorticans and Parkinsonia praecox allowed the reconstruction of the first chronology for both species in Argentina. The dendrochronological potential of both species was proven and supported by the statistics that characterize both chronologies in spite of contradictions regarding the possibility of dating G. decorticans (Tortorelli 1956, Giménez et al. 2013). Both species showed a significant correlation between series, 0.49 and 0.39 , respectively, which may imply a strong association between growth and environment, possibly connected to climatic conditions.

The mean radial growth of $G$. decorticans $(3.95 \mathrm{~mm}$ year ${ }^{-1}$ ) is similar to that of Prosopis caldenia (2.69 - 5.12 $\mathrm{mm}$ year ${ }^{-1}$ ) growing in the same area (Bogino and Villalba 2008) or in the province of La Pampa (2.2 - $4.52 \mathrm{~mm}$ year $\left.{ }^{-1}\right)$ (Bogino et al. 2015, Velasco et al. 2018). These results pointed out that woody species have similar growing rates even though they are dominant (P. caldenia), or codominant or intermediate ( $G$. decorticans) species. Furthermore, their growth rates are similar to the records of Pinus elliottii Engelm, an exotic species widely recommended for forestry purposes (Bogino et al. 2005), which is considered a worldwide invader nowadays. These annualized growth rates are highly valuable for further quantification of biomass and the estimation of the carbon fixing capacity of these systems.

The association between residual tree ring chronologies and climate showed, for both species, a significant inverse relationship with temperature. This variable controls other species growth in these environments such as P. caldenia (Bogino and Jobbágy 2011). Results clearly demonstrate that in a context of increased average temperature, both species would have growth limitations, which reinforces the idea of the vulnerability of arid and semi-arid systems to global warming (Pachauri et al. 2014). Concerning chañar, rainfall has a negative impact on summer growth. Considering that this species forms thickened groups of individuals favored by asexual reproduction and that all of them belong to the same tree, a more humid environment in summer may favor the growth of the younger individuals and limit it, in the case of the dominant trees sampled in this research. Regarding brea, rainfall previous to the growing season limited growth, showing a positive effect in summer (January). Further physiological studies are needed to understand why this humidity previous to the growing season can limit growth. Both species are vulnerable to local climatic factors (temperature and rainfall) although brea is also vulnerable to global forces (SOI), which is among the most important climatic variables regulating the planet's climate, meaning that the higher the SOI values, the lesser the growth rate. Since $P$. praecox was also vulnerable to SOI in the Guajira (Colombia), present results may contribute to consider a similar pattern of growth response of $P$. praecox to global drivers (Ramírez and Del Valle 2011).

Asexual reproduction by gemipherous roots is the most common way for the establishment of $G$. decorticans. Chañar forms thickened groups of trees known as small islands (islets), which makes it almost a unique species regarding this dynamic. These trees with the same genetic background growing together may be a factor that determines its limited response to climate in comparison with brea. In some cases, it is considered a native species expanding within the encroachment process (Rauber et al 2020), which may be the result of its climatic independence.

We concluded that starting from a general objective that proposes to reconstruct the temporal growth dynamics from the growth rings of G. decorticans and P. praecox and their association with climate, the construction of the first chronology of ring width was feasible for both species as well as the quantification of the annual growth rate. Dating both species was possible despite previous references questioning the feasibility of this process for $G$. decorticans. When interpreting the population and growth dynamics of both species based on environmental variables, a difference was found in this relationship according to the species. G. decorticans showed a connection with regional variables (temperature) while $P$. praecox is related to regional variables (temperature and rainfall) and global (SOI) ones. On the other hand, results reveal the capacity of pioneer species for carbon fixation and the adaptive climate response they possess with respect to main components of the forest (P. caldenia) and exotic components (Pinus elliottii Engelm.). These results also highlight the importance of an individual analysis of each of the components of forest systems since it is possible to assume a different environmental response in this context of global change. Therefore, the analysis of the system as a whole is relevant, emphasizing the impact of each intervening variables.

\section{ACKNOWLEDGMENT}

The authors would like to thank PROICO 140218 of Secretariat of Science and Technology of National University of San Luis, to the doctoral scholarship \#2271/15 by National Agricultural Technology Institute and National Scientific and Technical Research Council and to the owners of the private establishments where sampling was carried out.

\section{REFERENCES}

Anderson DL, JA Del Águila, AE Bernardón. 1970. Las formaciones vegetales en la provincia de San Luis. Revista de Investigaciones Agropecuarias, INTA 7(3): 153-158. 
Anderson D. 1976. Invasión del chañar (Geoffroea decorticans) en los pastizales de la Pcia de San Luis. RIA (7): 153-172.

Bar-On YM, R Phillips, R Milo. 2018. The biomass distribution on Earth. Proceedings of the National Academy of Sciences 115(25): 6506-6511. doi: 10.1073/pnas.1711842115.

Biondi F, K Waikul. 2004. Dendroclim 2002: a C ++ program for statistical calibration of climate signals in tree-ring chronologies. Comp Geoscience 30: 303-311. DOI: 10.1016/j. cageo.2003.11.004.

Bogino S, R Villalba. 2008. Radial growth and biological rotation age of Prosopis caldenia Burkart in Central Argentina. Journal of Arid Environments 72: 16-23. doi: 10.1016/j. jaridenv.2007.04.008.

Bogino S, E Jobbágy. 2011. Climate and groundwater effects on the establishment, growth and death of Prosopis caldenia trees in the pampas (Argentina). Forest Ecology and Management 262: 1766-1774. doi: 10.1016/j.foreco.2011.07.032.

Bogino S, M Gómez, A Avila, Z Furlán, S Escudero, A Corral, R Luna, R, J Martín García. 2005. Crecimiento de Pinus elliottii Engelm en el área serrana de la provincia de San Luis, Argentina. Revista Yvyraretá 13: 31-35.

Bogino S, C Roa Giménez, AT Velasco Sastre, ML Cangiano, L Risio, V Rozas. 2015. Synergistic effects of fire, grazing, climate, and management history on Prosopis caldenia recruitment in the Argentinean pampas. Journal of Arid Environments 117: 59-66. doi: 10.1016/j.jaridenv.2015.02.014.

Cabido D, MR Cabido, SM Garré, JA Gorgas, RA Miatello, AC Ravelo, L Argüello. 2003. Regiones naturales de la provincia de Córdoba. Córdoba, Argentina. Agencia Córdoba DACyT. $103 p$.

Cabrera AL.1976. Regiones fitogeográficas argentinas. Buenos Aires, Argentina. ACME. 85p.

Climatic research Unit, University of East Anglia. Accessed June 26, 2017. Available at https://crudata.uea.ac.uk/cru/data/soi/.

D’Ambrogio de Argüeso. 1986. Manual de Técnicas en Histología Vegetal. Buenos Aires, Argentina. Hemisferio Sur. 83p.

Di Rienzo J, M Balzarini, F Casanoves, L González, E Tablada, C Robledo. 2012. Infostat Software Estadístico versión 12. (on-line statistical software). Grupo infoStat, FCA, Universidad Nacional de Córdoba, Argentina. Last access 18 February 2020. Available at https://www.infostat.com.ar.

Dussart E G, C C Chirino, E Morici, R Peinetti. 2011. Reconstrucción del paisaje del caldenal pampeano en los últimos 250 años. Quebracho 19(1-2): 54-65.

Fritts HC. 2001. Tree rings and climate. Caldwell, USA. Blackburn Press. 567 p.

Giménez AM, JG Moglia. 2003. Árboles del Chaco Argentino. Guía para el reconocimiento dendrológico. Ed. Secretaria de Ambiente y Desarrollo Sustentable. Ministerio de Desarrollo Social Facultad de Ciencias Forestales. Santiago del Estero, Argentina. Universidad Nacional de Santiago del Estero. 307 p.

Giménez AM 2009. Anatomía de madera, corteza y anillos de crecimiento de Geoffroea decorticans (Gill., Ex Hook. et Arn.) Burk. Quebracho 17(1,2): 16-30.

Giménez AM, P Hernández, N Ríos, F Calatayu. 2013. Crecimiento de árboles individuales de Geoffroea decorticans, en un bosque del Chaco semiárido, Argentina. Madera y Bosques 19(1): 37-51.
Gorzelak MA, AK Asay, BJ Pickles, SW Simard. 2015. Interplant communication through mycorrhizal networks mediates complex adaptive behaviour in plant communities. AoB Plants 7. doi: 10.1093/aobpla/plv050.

Grissino-Mayer HD. 2001. Evaluating crossdating accuracy: a manual and tutorial for the computer program COFECHA. Tree-Ring Research 57: 205-221.

Iawa Committee. 1989. IAWA list of microscopic features for hardwood identification. IAWA Bulletin 10(3): 219-332.

Karlin MS, UO Karlin, RO Coirini, GJ Reati, RM Zapata. 2013. El Chaco Árido. Córdoba, Argentina. Universidad Nacional de Córdoba. 420 p.

Köppen W. 1931. Grundriss der klimakunde. Berlin, Deutschland. De Gruyter. 388p.

Martínez Carretero E. 1986. Ecología, Fitogeografía y Variación Intraespecífica de Cercidium praecox (Ruiz et Pavon) Harms. (Leguminosae) en Argentina. Documents Phytosociologiques 10(2): 319-329.

Medina A, E Dussart, D Estelrich, E Morici. 2000. Reconstrucción de la historia del fuego en un bosque de Prosopis caldenia (Burk.) de Arizona, sur de la provincia de San Luis. Multequina 9: 91-98.

Morales MS, R Villalba, JA Boninsegna. 2005. Climate, landuse and Prosopis ferox recruitment in the Quebrada de Humahuaca, Jujuy, Argentina. Dendrochronologia 22: 169-174. doi: 10.1016/j.dendro.2005.05.004.

Oliver CD, BC Larson. 1996. Forest Stand Dynamics (update edition). New York, USA. John Wiley. 544 p.

Oyarzabal M, JR Clavijo, LJ Oakley, F Biganzoli, PM Tognetti, IM Barberis, M Oesterheld. 2018. Unidades de vegetación de la Argentina. Ecología Austral 28: 40-63.

Pachauri RK, MR Allen, VR Barros, J Broome, W Cramer, R Christ, NK Dubash. 2014. Climate change 2014: synthesis report. Contribution of Working Groups I, II and III to the fifth assessment report of the Intergovernmental Panel on Climate Change (IPCC).151p.

Paez SA, DE Marco. 2000. Seedling habitat structure in dry Chaco forest (Argentina). Journal of Arid Environment 46: 57-68.

Peña Zubiate CA, DL Anderson, MA Demmi, JL Sáenz, A D'Hiriart. 1998. Carta de suelos y vegetación de la provincia de San Luis. San Luis, Argentina. Payne Publishing. 115p.

Ramírez J, I Del Valle. 2011. Local and global climate signals from tree rings of Parkinsonia praecox in La Guajira, Colombia. International Journal of Climatology 32: 10771088. doi: $10.1002 /$ joc. 2335.

Rauber RB, MR Demaría, D Arroyo, PA Cipriotti. 2020. Characterization of the herbaceous layer in woody thickets of Geoffroea decorticans in central Pampean grasslands. Phytocoenologia: 297-311. doi: 10.1127/phyto/2020/0357.

Ropelewski CF, PD Jones. 1987. An extension of the TahitiDarwin southern oscillation index. Monthly Weather Review 115(9): 2161-2165.

Schuch UK, JJ Kelly. 2008. Palo verde trees for the urban landscape. Aridus 20: 1-8.

Schulman E. 1956. Dendroclimatic changes in semiarid America. Arizona, EUA. University of Arizona Press. 142p.

Speer J. 2010. Fundamentals of tree-ring research. Tucson, USA. The University of Arizona Press. 333 p.

Tortorelli LA. 1956. Maderas y bosques argentinos. Buenos Aires, Argentina. ACME. 910p. 
Velasco Sastre T, M Vergarechea, A Tapia, E Dussart, J Leporati, S Bogino. 2018. Growth dynamics and disturbances along the last four centuries in the Prosopis caldenia woodlands of the Argentinean pampas. Dendrochronologia 47: 58-66. doi: 10.1016/j.dendro.2017.12.005.
Villagra PE, JA Boninsegna, JA Alvarez, M Cony, E Cesca, R Villalba. 2005. Dendroecology of Prosopis flexuosa woodlands in the Monte desert: Implications for their management. Dendrochronologia 22: 209-213. doi: 10.1016/j. dendro.2005.05.005.

Recibido: 10/09/20

Aceptado: 20/01/21 